\title{
Wet versterking positie curator: is de positie van de curator daadwerkelijk versterkt?
}

\author{
Mr. H.J. de Kloe en mr. F. Ortiz Aldana*
}

\begin{abstract}
Op 1 juli 2017 is de Wet versterking positie curator in werking getreden. In deze bijdrage wordt onderzocht of de curator er met deze wet rechten en instrumenten bijgekregen heeft en of zijn positie daadwerkelijk is versterkt. De inlichtingenen medewerkingsplicht in de Faillissementswet wordt geanalyseerd en vergeleken met de situatie vóór de wetswijziging.
\end{abstract}

\section{Inleiding}

De Wet versterking positie curator is op 1 juli 2017 in werking getreden en maakt onderdeel uit van het wetgevingsprogramma Herijking Faillissementsrecht, dat op 26 november $2012^{1}$ is aangekondigd. Het programma bestaat uit drie pijlers, te weten (1) modernisering van het faillissementsrecht, (2) versterking van het reorganiserend vermogen van bedrijven en (3) fraudebestrijding. De Wet versterking positie curator van 22 maart $2017^{2}$ valt onder de laatste pijler en bestaat zelf weer uit twee onderdelen, te weten (1) versterking van de fraudesignalerende functie van de curator en (2) versterking van de inlichtingen- en medewerkingsplicht van de failliet. ${ }^{3}$

In deze bijdrage staat het tweede onderdeel centraal: de versterking van de inlichtingen- en medewerkingsplicht van de failliet, de bestuurder van de failliete rechtspersoon, de partner van de failliet en overige derden. Het eerste onderdeel (versterking van de fraudesignalerende functie) geeft de curator geen nieuwe rechten, maar legt juist verplichtingen voor de curator vast. ${ }^{4}$ De vraag die in deze bijdrage wordt beantwoord, is of de

\footnotetext{
Mr. H.J. de Kloe is wetenschappelijk docent ondernemingsrecht en faillissementsrecht bij de sectie Handels- en Ondernemingsrecht \& Financieel Recht van de Erasmus School of Law te Rotterdam. Mr. F. Ortiz Aldana is advocaat en curator bij Dekker en Smits advocaten in Rosmalen.

1. Kamerstukken II 2012/13, 29911, 74 .

2. Stb. 2017, 124.

3. Kamerstukken II $2014 / 15,34253,3$, p. 1.

4. De curator heeft de verplichting om onderzoek te doen naar fraude, de rechter-commissaris hierover te informeren en indien door de curator of de rechter-commissaris gewenst aangifte of melding te doen bij de bevoegde instanties (art. 68 lid $2 \mathrm{Fw}$ ). Hierdoor wordt de positie van de curator niet versterkt, maar wordt zijn taak juist verzwaard. C.M. Harmsen stelt in haar artikel 'De curator en de bestrijding van fraude', Ondernemingsrecht 2014/78, zelfs de vraag of het eerste onderdeel van deze wet zou kunnen leiden tot een aanvullende aansprakelijkheidsgrond voor de curator indien hij zijn fraudesignalerende taak niet naar behoren heeft vervuld.
}

curator er met deze nieuwe wet rechten en instrumenten bij heeft gekregen en of zijn positie daadwerkelijk is versterkt. Om deze vraag te beantwoorden wordt de (informatie)positie van de curator onder oud recht vergeleken met zijn positie onder de Wet versterking positie curator. ${ }^{5}$

De opzet is als volgt. In paragraaf 2 wordt de inlichtingen- en medewerkingsplicht van de failliet en bestuurders van een failliete rechtspersoon behandeld. Paragraaf 3 handelt over de inlichtingenplicht van de echtgenoot of de geregistreerd partner met wie de failliet een gemeenschap van goederen is aangegaan en paragraaf 4 over de verplichtingen van derden. Ten aanzien van elk onderwerp wordt eerst onderzocht wat de situatie was voor de wetswijziging, waarna een vergelijking wordt gemaakt met de Wet versterking positie curator. Aan de hand van die vergelijking wordt geanalyseerd of de curator er daadwerkelijk rechten en/of instrumenten bij heeft gekregen, waardoor zijn (informatie)positie is versterkt, zoals de titel van de wet doet vermoeden.

\section{Inlichtingen- en medewerkingsplicht failliet en bestuurder}

Voor een voortvarende afwikkeling van de boedel moet de curator kunnen rekenen op informatie en de medewerking van de failliet, en in het geval dat een rechtspersoon is, van de bestuurder van de failliet. De Wet versterking positie curator heeft in deze informatie- en medewerkingsplicht veranderingen gebracht.

\subsection{Inlichtingen-en medewerkingsplicht failliet en bestuurders voor de wetswijziging}

De inlichtingenplicht van de failliet was vastgelegd in artikel 105 lid 1 van de Faillissementswet (Fw) (oud). ${ }^{6}$ Deze inlichtingenplicht werd in de praktijk ruim geïnterpreteerd. Zo was het vaste jurisprudentie dat de failliet ook uit eigen beweging inlichtingen moest verschaffen over feiten en omstandigheden die - kort gezegd - van belang waren voor de afwikkeling van

\footnotetext{
5. De oude en nieuwe bepalingen zijn als bijlage bij dit artikel gevoegd.

6. De wetteksten van art. 105 en $106 \mathrm{Fw}$ onder oud recht en na inwerkingtreding van de Wet civielrechtelijk bestuursverbod zijn als bijlage bij dit artikel opgenomen.
} 
het faillissement. ${ }^{7}$ De inlichtingenplicht was daarnaast niet beperkt tot feiten en omstandigheden waarvan de persoon uit hoofde van zijn functie kennis droeg, en ook niet tot zijn eigen administratie, maar kon tevens zien op inlichtingen die betrekking hadden op het vermogen van gelieerde (rechts)personen die niet failliet waren. ${ }^{8}$

Hoewel dit niet in de wet was opgenomen, volgde uit jurisprudentie dat de failliet een medewerkingsplicht had. Deze medewerkingsplicht lag naar het oordeel van de Hoge Raad besloten in de Faillissementswet, in het bijzonder in de vierde afdeling van de eerste titel. ${ }^{9}$ Hieronder viel bijvoorbeeld de plicht om de curator alle medewerking te verlenen bij het te gelde maken van in het buitenland gelegen activa. ${ }^{10}$ In een uitspraak van de Rechtbank Rotterdam is voorts aangenomen dat de medewerkingsplicht inhield dat de (bestuurder van de) failliet zich in het kader van de afwikkeling van het faillissement moest richten naar de aanwijzingen van de curator. ${ }^{11}$ Ook was de (bestuurder van de) failliet verplicht om de administratie ter beschikking te stellen aan de curator, met de middelen om deze administratie leesbaar te maken. ${ }^{12}$ In de literatuur was discussie over de vraag of de plicht van de failliet tot overlegging van de administratie aan de curator voortvloeide uit de medewerkingsplicht ${ }^{13}$ of de inlichtingenplicht. ${ }^{14}$ Wat de grondslag ook was, niet ter discussie stond dat de failliet verplicht was zijn administratie te overleggen aan de curator. Schending van deze verplichting was (en is) strafbaar gesteld in het Wetboek van Strafrecht $(\mathrm{Sr}) .^{15}$

Op grond van artikel $106 \mathrm{Fw}$ (oud) rustte de inlichtingenplicht mede op bestuurders en commissarissen van een failliete rechtspersoon. Aan de hand van de strekking van artikel 106 $\mathrm{Fw}$ is de informatieplicht van bestuurders in de loop der jaren in de rechtspraak uitgebreid. Naar het oordeel van de Hoge Raad heeft de wetgever met artikel 106 Fw het oog gehad op personen die ten tijde van de faillietverklaring bestuurder waren. De inlichtingenplicht rustte daarmee tevens op degene die tijdens het faillissement zijn hoedanigheid van bestuurder

7. HR 15 februari 2002, JOR 2002/91.

8. Zie hierover M.W. Steenpoorte, Ontwikkelingen rond de inlichtingenen medewerkingsplicht van de failliet en betrokken derden, FIP 2015/369, met verwijzing naar rechtspraak. Zie ook Rb. Oost-Brabant (vzr.) 20 oktober 2014, JOR 2015/215, r.o. 4.3.

9. HR 23 december 1983, NJ 1985/170.

10. Hof Den Haag 6 oktober 2011, JOR 2012/162 (Van der Weide q.q./ $\mathrm{X})$, r.o. 8 .

11. Rb. Rotterdam 5 juni 2013, JOR 2014/179, r.o. 4.2.

12. Zie bijv. F.B. Bosvelt \& A.R. van Oijen, Cloud computing in faillissement en surseance. Beter één administratie in de hand dan tien in de lucht?, TvI 2013/39.

13. Bosvelt \& Van Oijen 2013. De MvT bij de Wet versterking positie curator lijkt aan te sluiten bij deze opvatting, Kamerstukken II 2014/15, 34253, 3, p. 19 en 20.

14. B. Wessels, Insolventierecht IV. Bestuur en beheer na faillietverklaring, Deventer: Wolters Kluwer 2015/4400; L.I. Couwenberg, Commentaar op Faillissementswet artikel 105, in: N.E.D. Faber e.a. (red.), Sdu Commentaar Insolventierecht, laatst bijgewerkt: 8 mei 2017.

15. Vanaf 1 juli 2016 in art. $344 a$ lid 1 onder $1 \mathrm{Sr}$, daarvoor in art. 340 onder $3^{\circ}, 341$ onderdeel a onder $4^{\circ}, 342$ onder $3^{\circ}$ en 343 onder $4^{\circ} \mathrm{Sr}$. verloor. ${ }^{16}$ Op basis van een teleologische interpretatie is de inlichtingenplicht in lagere rechtspraak ook voor de feitelijk beleidsbepaler ${ }^{17}$ en de middellijk bestuurder ${ }^{18}$ gaan gelden. In lagere rechtspraak is ook aangenomen dat de inlichtingenplicht onder omstandigheden mede rust op een gewezen bestuurder. ${ }^{19}$ In de literatuur is voorts verdedigd dat de inlichtingenplicht ook zou moeten gelden voor de lokale manager in Nederland van een buitenlandse rechtspersoon. ${ }^{20}$

A-G Huydecoper schreef in zijn conclusie bij een beschikking van de Hoge Raad van 17 januari 2003 dat voor de vraag voor welke personen de inlichtingenplicht geldt, beslissend was of de betrokkene te eniger tijd in de hoedanigheid van bestuurder of feitelijk leidinggevende heeft gefunctioneerd, ongeacht of de betrokkene ten tijde van de faillietverklaring nog in die hoedanigheid functioneerde. Het ging erom of de betrokkene, uit hoofde van zijn optreden als bestuurder, beschikte over informatie die voor de curator van belang kan zijn. Daarom strekten de verplichtingen van artikel 105 en $106 \mathrm{Fw}$ (oud) zich ook uit tot bestuurders die de hoedanigheid van bestuurder al lang waren verloren, aldus A-G Huydecoper. Waar het om ging, is niet dat zij (nog) bestuurder waren, maar dat zij over informatie (konden) beschikken die voor de afwikkeling van het faillissement van belang was. ${ }^{21}$ Naar onze mening is dit een juiste interpretatie van artikel $106 \mathrm{Fw}$ (oud). Hoewel dat niet naar voren komt uit de rechtspraak, is het onzes inziens verdedigbaar dat de inlichtingenplicht op basis van een ruime teleologische interpretatie van artikel $106 \mathrm{Fw}$ (oud) van toepassing was op iedere gewezen bestuurder die informatie kon verschaffen die voor de afwikkeling van het faillissement

16. HR 17 november 1972, NJ 1973/133 (Faill. Westerhof).

17. Rb. 's-Hertogenbosch 9 september 1981, NJ 1982/131 en Hof Den Haag 9 juli 2013, ECLI:NL:GHDHA:2013:3391.

18. Rb. Amsterdam 2 februari 1982, NJ 1982/525; Rb. Rotterdam 3 mei 2012, JOR 2013/79.

19. Zie bijv. Rb. Amsterdam 17 november 1982, NJ 1984/139 (De Pauw), waarbij van belang was dat de gewezen bestuurder tot de datum van faillietverklaring feitelijk het beleid van de vennootschap bepaalde, Rb. Roermond 8 maart 1984, NJ 1985/348, waarbij de bestuurder tussen het faillissementsverzoek en de faillietverklaring ontslag had genomen, Hof Den Haag 21 mei 2013, ECLI:NL:GHDHA:2013:CA2593, waarbij de bestuurder in het zicht van het faillissement ontslag had genomen, en Hof Den Haag 9 juli 2013, ECLI:NL:GHDHA:2013:3391, waarbij de rechtbank in eerste aanleg overwoog dat de inlichtingenplicht ook kon rusten op personen die 'in een wat verder verleden' bestuurder of feitelijk beleidsbepaler waren. Het hof was van oordeel dat de persoon in kwestie ten tijde van de faillietverklaring feitelijk beleidsbepaler was en ging niet in op de gewezen bestuurder of feitelijk beleidsbepaler. Anders: Rb. Rotterdam 3 mei 2012, JOR 2013/79.

20. C.M. Hilverda, Faillissementsfraude (Serie Onderneming en Recht, deel 53), Deventer: Kluwer 2009, p. 46; Wessels Insolventierecht IV 2015/4407. Zie ook W.J.B. van Nielen \& C.M. Derijks, De curator als civiele fraudebestrijder. Kanttekeningen bij het Voorontwerp versterking positie curator voor de bestrijding van faillissementsfraude, TBS\&H 2014, afl. 1, p. 27.

21. Concl. A-G Huydecoper bij HR 17 januari 2003, ECLI:NL:PHR: 2003:AF0206, par. 16 


\section{Maandblad}

Ondernemingsrecht

van belang was. ${ }^{22}$ De memorie van toelichting bij artikel 106 Fw (oud) sluit hier ook op aan. De inlichtingenplicht rust op de bestuurders, omdat zij 'de eenige personen [zijn] die deze verplichtingen uit den aard der zaak kunnen vervullen'. ${ }^{23} \mathrm{Als}$ een gewezen bestuurder de enige was die inlichtingen kon verstrekken over een bepaald onderwerp, lag het gelet op de bedoeling van de wetgever voor de hand dat hij ook verplicht was deze inlichtingen te verstrekken.

Artikel 106 Fw (oud) sprak alleen over de bestuurder en commissaris van een rechtspersoon, niet over de vennoot van een personenvennootschap. Voor deze bijdrage voert het te ver om de inlichtingenplicht bij de personenvennootschap uitvoerig te bespreken. ${ }^{24} \mathrm{We}$ volstaan daarom met een enkele opmerking. Vóór 6 februari 2015 was de vraag naar de inlichtingenplicht bij personenvennootschapen in de praktijk vrijwel nooit relevant, omdat het faillissement van een personenvennootschap altijd ook het faillissement van de vennoten betekende. In februari 2015 is de Hoge Raad op dat punt omgegaan. ${ }^{25}$ Vanaf dat moment moet het faillissement van de vennoten afzonderlijk van dat van de VOF worden uitgesproken. Wel overweegt de Hoge Raad dat, na de faillietverklaring van een VOF, het faillissement van de vennoten doorgaans onvermijdelijk is en dat het daarom wenselijk is dat de faillissementen van de VOF en de vennoten tegelijk worden uitgesproken en afgewikkeld. Ook vanaf februari 2015 volgt het faillissement van de vennoten in de regel dan ook op dat van de VOF. De curator kan de failliete vennoten daarom meestal hoe dan ook aanspreken op hun inlichtingenplicht. Daarnaast volgt naar onze mening uit de bedoeling van de wetgever bij artikel 106 Fw (oud) dat de inlichtingenplicht ook rustte op de vennoten van een personenvennootschap. De wetgever heeft de inlichtingenplicht immers willen leggen op de personen die deze verplichting 'uit den aard der zaak' kunnen vervullen. In het geval van een personenvennootschap zijn dat de vennoten. Als de vennoten zélf rechtspersonen zijn, dan zijn dat de natuurlijke personen die bestuurder of feitelijk beleidsbepaler zijn van deze rechtspersonen.

22. Vgl. Hilverda, die ervoor pleitte om de inlichtingenplicht te laten rusten op degene die bestuurder was op het moment dat de rechtspersoon feitelijk in de faillissementstoestand verkeerde (Hilverda 2009, p. 49-50). Veelal werd overigens aangenomen dat de inlichtingenplicht in beginsel niet rustte op de gewezen bestuurder, zie bijv. R. Mulder, 'It takes two to tango'. Informatieverschaffing door de gefailleerde aan de curator en van de curator aan de gefailleerde, in: J.J. Reiziger \& A. van der Schee (red.), De curator en informatie (INSOLAD Jaarboek 2013), Deventer: Kluwer 2013, p. 2 en R.M. Vermaire \& J.M. Luijkx, Een curator die steviger in zijn schoenen staat? Over het wetsvoorstel versterking positie curator, FIP 2016/84.

23. G.W. Baron van der Feltz (red.), Geschiedenis van de wet op het faillissement en de surséance van betaling. Deel II, Haarlem: Erven F. Bohn 1896 (hierna: Van der Feltz II; Van der Feltz I (voor Deel I), herdrukt in: S.C.J.J. Kortmann \& N.E.D. Faber (red.), Geschiedenis van de Faillissementswet. Deel 2-II, Zwolle: W.E.J. Tjeenk Willink 1994, p. 70.

24. Zie voor een uitvoerige bespreking van art. $106 \mathrm{Fw}$ en personenvennootschappen H.J. de Kloe, Personenvennootschappen en de inlichtingenplicht tijdens faillissement, TvI 2018/12.

25. HR 6 februari 2015, ECLI:NL:HR:2015:251, JOR 2015/181 (VDV Totaalbouw).

\subsection{Wet versterking positie curator}

De Wet versterking positie curator is grotendeels een codificatie van de hiervoor weergegeven jurisprudentie. $\mathrm{Zo}$ is $\mathrm{nu}$ in artikel 105 lid $1 \mathrm{Fw}$ de plicht vastgelegd om zowel gevraagd als ongevraagd inlichtingen te verstrekken. De verplichting om de curator te informeren over buitenlandse vermogensbestanddelen en mee te werken aan het beheer over en de vereffening van dit vermogen door de curator gold reeds voor de wetswijziging en is thans neergelegd in artikel 105 lid 2 Fw. De medewerkingsplicht is gecodificeerd in artikel 105a lid 1 Fw en de verplichting om de administratie te overleggen aan de curator, met daarbij de middelen om deze binnen redelijke termijn leesbaar te maken, in artikel 105a lid 2 Fw. In artikel 106 lid 1 $\mathrm{Fw}$ is voorts opgenomen dat de inlichtingen- en medewerkingsplicht ook geldt voor degene die in de drie jaar voorafgaand aan de faillietverklaring van een rechtspersoon bestuurder of commissaris was. Artikel 106 lid 2 Fw bepaalt dat de inlichtingen- en medewerkingsplicht ook rust op de feitelijk beleidsbepaler en middellijk bestuurder van een rechtspersoon. Volgens artikel 106 lid 3 Fw rust de inlichtingenplicht ook op de vennoten/bestuurders van een VOF of CV. Tot zover is er niets nieuws onder de zon. Wel vallen er kanttekeningen te maken bij deze codificatie.

De wetgever heeft nagelaten te codificeren dat de inlichtingenplicht niet beperkt is tot feiten en omstandigheden waarvan de persoon uit hoofde van zijn functie kennis draagt, maar dat deze mede ziet op inlichtingen die betrekking hebben op het vermogen van gelieerde (rechts)personen die niet failliet zijn. Dit lijkt ons een gemiste kans. Wij nemen aan dat de wetgever niet heeft beoogd om de inlichtingenplicht op dit punt te beperken en verwachten dat de hierover gewezen jurisprudentie derhalve relevant blijft bij de uitleg en toepassing van artikel 105 lid 1 Fw.

Verder valt in de memorie van toelichting bij artikel 105a lid 1 Fw te lezen dat de medewerkingsplicht begrensd is indien de vereiste medewerking in redelijkheid niet van de failliet kan worden gevergd op grond van zwaarwegende omstandigheden. Daarbij valt volgens de memorie van toelichting te denken aan een onevenredige inbreuk op zijn persoonlijke levenssfeer of de doorbreking van de vertrouwelijkheid van de correspondentie tussen cliënt en advocaat. Een beslissing hierover is voorbehouden aan de rechter-commissaris. ${ }^{26}$ Hoewel het terecht is dat de medewerkingsplicht niet van toepassing is onder specifieke zwaarwegende omstandigheden, hebben Van Nielen en Derijks ${ }^{27}$ er onzes inziens terecht op gewezen dat dit extra werkzaamheden bij de rechter-commissaris legt en 'vertragingstactieken' in de hand kan werken. Gefailleerden die de curator dwars willen zitten, kunnen, ook als zij weten dat een dergelijk verzoek geen kans van slagen heeft, te pas en te onpas een verzoek bij de rechter-commissaris indienen met als reden dat sprake is van zwaarwegende omstandigheden die derogeren aan hun medewerkingsplicht. De drempel hiervoor is laag,

26. Kamerstukken II 2014/15, 34253, 3, p. 20.

27. Van Nielen \& Derijks 2014, p. 29. 
omdat hiervoor geen verplichte procesvertegenwoordiging geldt. Tegen een beslissing van de rechter-commissaris op een dergelijk verzoek staat beroep open bij de rechtbank (art. 67 Fw). De failliet heeft hiermee een middel om de afwikkeling van een faillissement te vertragen. ${ }^{28}$ Dit kan in de praktijk tot problemen leiden voor de curator.

Ook kan de vraag of iemand al dan niet feitelijk beleidsbepaler is en daarmee op hem of haar de inlichtingen- en medewerkingsplicht van toepassing is, moeilijkheden met zich brengen. Uit de memorie van toelichting volgt dat ten aanzien van het begrip feitelijk beleidsbepaler is angesloten bij artikel 2:138/248 lid 7 van het Burgerlijk Wetboek (BW). ${ }^{29}$ Indien de curator tegenover een (vermeend) feitelijk beleidsbepaler een beroep doet op de inlichtingen- en medewerkingsplicht en daaraan geen gehoor wordt gegeven, dan kan de curator de rechter-commissaris verzoeken om een verhoor op grond van artikel $105 \mathrm{Fw}$ in te plannen, eventueel gevolgd door een verzoek om gijzeling op grond van artikel 87 lid $1 \mathrm{Fw}$. Als de rechter-commissaris iemand oproept voor een verhoor op grond van artikel $105 \mathrm{Fw}$, dient hij of zij te beoordelen of deze persoon al dan niet aangemerkt moet worden als feitelijk beleidsbepaler. De rechtbank, die het verzoek tot gijzeling beoordeelt, zal bij discussie ook moeten beoordelen of de persoon in kwestie al dan niet als feitelijk beleidsbepaler kan worden aangemerkt. Een probleem daarbij is dat vaak eerst nadat inlichtingen zijn verstrekt en de curator de beschikking heeft over de volledige administratie, aantoonbaar is of iemand zich daadwerkelijk heeft gedragen als feitelijk beleidsbepaler. Om informatieverplichtingen die voortvloeien uit de Faillissementswet af te kunnen dwingen, zou het naar onze mening daarom afdoende moeten zijn dat de curator daarvoor aannemelijk maakt dat iemand feitelijk beleidsbepaler is.

Dat de inlichtingenplicht op grond van artikel 106 lid 1 Fw ook geldt voor gewezen bestuurders, valt toe te juichen. Veelal werd immers aangenomen dat - tenzij sprake was van bijzondere omstandigheden - de inlichtingenplicht niet van toepassing was op gewezen bestuurders. Hiervóór hebben wij aangegeven dat verdedigbaar is dat de inlichtingenplicht voor de wetswijziging van toepassing was op iedere gewezen bestuurder die informatie kon verschaffen die voor de afwikkeling van het faillissement van belang was. Naar huidig recht is de inlichtingenplicht expliciet beperkt tot de personen die in de drie jaar voorafgaand aan de faillietverklaring de hoedanigheid

28. Naast de steeds populairder wordende gang naar de Toetsingscommissie van INSOLAD om daar het functioneren van de curator aan de kaak te stellen. Zie het (niet-uitputtende) overzicht dat Rinke Dulack in zijn artikel in TvI 2017/11 heeft gegeven van beslissingen in de periode 2010-2016. Uit zijn overzicht blijkt dat er in de eerste jaren relatief weinig klachten waren; vanaf 2012 nam dat toe en vanaf medio 2014 worden er geleidelijk meer klachten ingediend. Dulack signaleert verder vanaf eind 2014 een toegenomen neiging van de Toetsingscommissie om art. 4 lid 5 van het Toetsingsreglement buiten beschouwing te laten door verzoekers die zich al zonder succes tot de rechter-commissaris hebben gewend of een andere procedure tegen de curator hebben gevoerd, in hun klacht te ontvangen.

29. Kamerstukken II 2014/15, 34253, 3, p. 24. van bestuurder bezaten. ${ }^{30}$ Wie langer geleden bestuurder was en relevante informatie voor de curator heeft, blijft buiten schot. De wet stelt thans een beperking in tijd van de kring van personen op wie de inlichtingenplicht van toepassing is, terwijl deze beperking voor de wetswijziging niet gold. Van Nielen en Derijks hebben er al op gewezen dat deze beperking in tijd fraudeurs in de kaart speelt. ${ }^{31}$ Wie buiten schot wil blijven, dient simpelweg een katvanger te vinden die de vennootschap nog minstens drie jaar laat bungelen alvorens het faillissement wordt aangevraagd. Overigens makt dit in de praktijk voor de inlichtingenplicht in de regel niet uit. Degenen op wie de inlichtingenplicht niet rust, kunnen op grond van artikel $66 \mathrm{Fw}$ door de rechter-commissaris worden gehoord als getuigen. ${ }^{32}$ Iemand die opgeroepen wordt als getuige, is verplicht getuigenis af te leggen, tenzij hij zich kan verschonen op grond van artikel 66 lid 4 Fw. ${ }^{33}$ De medewerkingsplicht, waaronder de plicht tot het overleggen van de administratie, rust alleen op de personen die genoemd worden in artikel $106 \mathrm{Fw}$. In dat kader is het een gemis dat artikel 106 lid $1 \mathrm{Fw}$ beperkt is tot degenen die tot drie jaar voor het faillissement bestuurder waren. Naar onze mening is de positie van de curator daarom weliswaar verduidelijkt omdat in de wet opgenomen is dat de inlichtingen- en medewerkingsplicht rust op de gewezen bestuurder, maar anderzijds verzwakt omdat deze plichten niet meer gelden voor alle gewezen bestuurders.

Tot slot is in de wet niet opgenomen dat de inlichtingen- en medewerkingsplicht zich ook uitstrekt tot de lokale manager in Nederland van een buitenlandse rechtspersoon. De inlichtingenplicht rust wel op de lokale manager als hij of zij feitelijk beleidsbepaler is in de zin van artikel 106 lid 2 onder a Fw, maar in veel gevallen zal de lokale manager het beleid uitvoeren dat 'van hogerhand' is opgelegd. Voor de curator kan het zinvol zijn als de inlichtingen- en met name de medewerkingsplicht ook rusten op de lokale manager die geen bestuurder of feitelijk beleidsbepaler is, omdat deze persoon voor de curator beter bereikbaar is dan buitenlandse bestuurders en 'uit den aard der zaak' beter in staat kan zijn om gegevens te verstrekken die nodig zijn voor de afwikkeling van het faillissement. ${ }^{34}$ Op dit punt is de positie van de curator ten onrechte niet versterkt.

30. De wetgever heeft deze periode beperkt tot drie jaar om aan te sluiten bij art. 2:138 en 2:248 BW en het civielrechtelijk bestuursverbod, zie Kamerstukken II 2014/15, 34253, 3, p. 23.

31. Van Nielen \& Derijks 2014, p. 28.

32. Zo ook W.J.B. van Nielen, Middelen van de curator bij faillissementsfraude, TvI 2013/13. Vgl. Hof Arnhem-Leeuwarden 28 december 2017, ECLI:NL:GHARL:2017:11486, r.o. 3.8 en HR 23 december 2016, NJ $2017 / 27$.

33. Zie art. 165 lid $1 \mathrm{Rv}$. Weliswaar is art. $165 \mathrm{Rv}$ niet expliciet van toepassing verklaard op een getuigenverhoor op grond van art. $66 \mathrm{Fw}$, maar art. 172 en 173 lid 1, eerste volzin, 2 en 3 Rv zijn wel van toepassing op een getuigenverhoor door de rechter-commissaris op grond van art. 66 lid 3 Fw. Art. 172 Rv houdt in dat de rechter verschijning van een getuige kan bevelen en op grond van art. $173 \mathrm{Rv}$ kan een weigerachtige getuige worden gegijzeld.

34. Vgl. Hilverda 2009, p. 46. 


\section{Maandblad}

Ondernemingsrecht

\section{Inlichtingenplicht partner}

Op degene die in enige gemeenschap van goederen is gehuwd of een geregistreerd partnerschap is aangegaan, rusten ook verplichtingen op grond van de Faillissementswet. Uit artikel 63 lid $1 \mathrm{Fw}$ volgt dat het faillissement van een schuldenaar die in enige gemeenschap van goederen is gehuwd of een geregistreerd partnerschap is aangegaan, als het faillissement van de gemeenschap wordt behandeld. Het faillissement omvat alle goederen die in de gemeenschap vallen en strekt ten behoeve van alle schuldeisers die op de goederen van de gemeenschap verhaal hebben. Vaak kunnen beide partners de gemeenschap binden. ${ }^{35}$ Omdat de echtgenoot of geregistreerd partner (de echtgenoot en geregistreerd partner worden hierna aangeduid als 'partner') van de failliet invloed kan hebben gehad op de boedel, is het gerechtvaardigd dat ook informatieverplichtingen rusten op de partner ten aanzien van de gemeenschap van goederen. ${ }^{36}$

Op grond van artikel 105 lid $3 \mathrm{Fw}$ rust de inlichtingenplicht ook op de partner van de failliet, voor zover het faillissement de gemeenschap betreft. Artikel 105a lid 3 Fw bepaalt hetzelfde ten aanzien van de medewerkingsplicht. Onderzocht wordt of met deze bepalingen sprake is van een versterking van de positie van de curator. Ook wordt ingegaan op de verhouding tussen artikel 105 lid $3 \mathrm{Fw}$ en het verschoningsrecht.

\subsection{Verplichtingen partner voor de wetswijziging}

De inlichtingenplicht voor de partner van de failliet was geregeld in artikel 105 lid $2 \mathrm{Fw}$ (oud). Volgens artikel 105 lid $2 \mathrm{Fw}$ (oud) rustte op de partner een inlichtingenplicht, voor zover deze in gemeenschap van goederen was gehuwd of een geregistreerd partnerschap was aangegaan. Deze inlichtingenplicht strekte niet verder dan de gemeenschap van goederen. Uit de wet volgde niet dat de partner een inlichtingenplicht had als sprake was van een beperkte gemeenschap. In artikel 63 lid 1 $\mathrm{Fw}$ is wel bepaald dat het faillissement van de persoon die in enige gemeenschap van goederen is gehuwd of een geregistreerd partnerschap is aangegaan, als het faillissement van de gemeenschap wordt behandeld. Uit de wetsgeschiedenis volgt dat, ondanks het verschil in redactie, geen materieel verschil is bedoeld tussen artikel 63 lid $1 \mathrm{Fw}$ en artikel 105 lid $2 \mathrm{Fw}$ (oud). ${ }^{37}$ Ook onder oud recht rustte er dus een inlichtingenplicht op de partner die een beperkte gemeenschap van goederen had met de failliet. De Faillissementswet bood de curator geen middelen om de partner te dwingen inlichtingen te verstrekken. Het was niet mogelijk om de partner te gijzelen wegens het niet voldoen aan de inlichtingenplicht. ${ }^{38}$

Voor de wetswijziging rustte uitsluitend een inlichtingenplicht op de partner voor zover hij of zij zelf had gehandeld. De partner kon wel op grond van artikel 66 lid $1 \mathrm{Fw}$ door de rechter-commissaris worden opgeroepen om als getuige ophel-

\footnotetext{
35. Zie o.a. art. 1:94 lid 2 en 1:97 lid 1 BW.

36. Van der Feltz II, p. 69.

37. Van der Feltz I, p. 540.

38. HR 25 juni 1976, NJ 1977/495.
}

dering te verschaffen over het handelen van de failliet ten aanzien van de gemeenschap van goederen. De partner had dan de mogelijkheid zich te verschonen op grond van artikel 66 lid 4 Fw. Het verschoningsrecht van artikel 66 lid $4 \mathrm{Fw}$ was echter niet van toepassing als het ging om het eigen handelen van de partner. ${ }^{39}$

In paragraaf 2 is reeds aangegeven dat de medewerkingsplicht van de failliet naar het oordeel van de Hoge Raad besloten lag in de Faillissementswet, in het bijzonder in de vierde afdeling van de eerste titel. ${ }^{40}$ Deze afdeling is niet zonder meer van toepassing op de partner van de failliet. Hiervoor is reeds aangegeven dat de partner niet gegijzeld kon worden wegens het niet voldoen aan de inlichtingenplicht. De bepalingen over inbewaringstelling (art. $87 \mathrm{t} / \mathrm{m} 90 \mathrm{Fw}$ ) waren dus niet van toepassing op de partner. De Hoge Raad voerde hiervoor als reden aan dat de inlichtingenplicht van de partner wél geregeld was in artikel 105 lid $2 \mathrm{Fw}$ (oud), maar dat artikel $87 \mathrm{Fw}$ zweeg over de partner. ${ }^{41} \mathrm{Nu}$ de medewerkingsverplichting voortvloeide uit een afdeling die (in ieder geval deels) niet van toepassing was op de partner, lijkt het ons voor de hand te liggen dat de medewerkingsverplichting voor de wetswijziging niet voor de partner gold.

\subsection{Wet versterking positie curator}

Door de Wet versterking positie curator is expliciet in artikel 105 lid $3 \mathrm{Fw}$ opgenomen dat de inlichtingenplicht ook rust op degene die in enige gemeenschap is gehuwd of een geregistreerd partnerschap is aangegaan. Omdat dit voor de wetswijziging ook het geval was op grond van artikel 105 lid $2 \mathrm{Fw}$ (oud), is de positie van de curator met deze wijziging niet versterkt. ${ }^{42}$ De wettelijke vastlegging kan wel als een verduidelijking worden gezien.

De inlichtingenplicht van de partner blijft beperkt tot de gemeenschap van goederen, maar is niet meer beperkt tot het eigen handelen. ${ }^{43}$ Onder huidig recht is het de vraag of de partner inlichtingen over het handelen van de failliet kan weigeren met een beroep op het verschoningsrecht, als de failliet met die informatie geïncrimineerd wordt. Het verschoningsrecht vloeit ten aanzien van een getuige zelf voort uit het nemo tenetur-beginsel van artikel 6 van het Europees Verdrag tot bescherming van de rechten van de mens en de fundamentele vrijheden (EVRM), inhoudende dat niemand verplicht is om bewijs te leveren dat kan bijdragen aan zijn strafrechtelijke veroordeling. ${ }^{44}$ Als het gaat om een familielid van een getuige, is de ratio van het verschoningsrecht de bescherming van de

39. Zie de noot van B. Wessels onder HR 15 februari 2002, NJ 2002/259

40. HR 23 december 1983, NJ 1985/170.

41. HR 25 juni 1976, NJ 1977/495.

42. De MvT bij de Wet versterking positie curator lijkt (ten onrechte) anders te suggereren, zie Kamerstukken II 2014/15, 34253, 3, p. 19.

43. Art. 105 lid 3 Fw, zie ook Kamerstukken II 2014/15, 34253, 3, p. 19.

44. HR 11 februari 1994, NJ 1994/336, r.o. 3.2. 
familierelatie en het voorkomen dat het familielid voor een moreel dilemma wordt gesteld. ${ }^{45}$

Daarmee is niet gezegd dat het verschoningsrecht ook van toepassing is op de inlichtingenplicht van de partner. Ten aanzien van de inlichtingenplicht van de failliet zélf heeft de Hoge Raad geoordeeld dat geen sprake is van strijd met artikel 6 EVRM, als door gijzeling dwang wordt uitgeoefend op de failliet om inlichtingen te verstrekken. Indien in een procedure tot (beëindiging van de) gijzeling een beroep wordt gedaan op het nemo tenetur-beginsel, dan dient de rechter in zijn uitspraak op te nemen dat de te verstrekken inlichtingen (voor zover het 'wilsafhankelijk materiaal' betreft) uitsluitend worden gebruikt ten behoeve van de afwikkeling van het faillissement. ${ }^{46}$ Naar onze mening moet een beroep van de partner op het verschoningsrecht op vergelijkbare wijze worden gewaarborgd. De partner die op grond van artikel 105 lid 3 Fw inlichtingen moet verstrekken, wordt niet gehoord als getuige. Het verschoningsrecht is daarom niet rechtstreeks van toepassing op artikel 105 lid 3 Fw. ${ }^{47}$ Op de partner kan druk worden uitgeoefend om inlichtingen te verstrekken die de failliet incrimineren. De partner kan weliswaar niet worden gegijzeld wegens het niet voldoen aan de inlichtingenplicht, maar wel pleegt de partner die niet voldoet aan de inlichtingenplicht een strafbaar feit op grond van artikel 194 Sr. Daarmee wordt de partner voor hetzelfde dilemma geplaatst als bij een getuigenverhoor en is artikel 165 lid 3 van het Wetboek van Burgerlijke Rechtsvordering $(\mathrm{Rv})$ naar onze mening, gelet op de ratio van het verschoningsrecht, analoog van toepassing op artikel 105 lid 3 Fw. De partner zou naar analogie van artikel 165 lid 3 Rv een beroep kunnen doen op het verschoningsrecht ten aanzien van specifieke informatie waarmee de failliet geïncrimineerd wordt. Bij een dergelijk beroep op het verschoningsrecht moeten de inlichtingen alsnog worden verstrekt, maar zal (waar het 'wilsafhankelijk materiaal' betreft) gewaarborgd moeten worden dat de inlichtingen uitsluitend gebruikt worden ten behoeve van de afwikkeling van het faillissement. De curator kan een dergelijke waarborg niet geven. De partner zal een beroep moeten doen op de rechter-commissaris om deze restrictie te verbinden aan de te geven inlichtingen. Zodra deze restrictie is gegeven, dient de partner de verzochte inlichtingen te verstrekken.

45. Asser Procesrecht/Asser 3 2013/137. Zie ook EHRM 24 november 1986, NJ 1988/745, par. 30.

46. HR 24 januari 2014, NJ 2014/70. Zie over de Wet versterking positie curator en het nemo tenetur-beginsel o.a. W.J.B. van Nielen, Wet versterking positie curator: financiering, fraudespreekuur, nemo tenetur beginsel, FIP 2017/168, E.M. Moerman, De nieuwe rol van de curator in de fraudebestrijding: knelpunt in aanloop naar een eventueel strafproces?, TBS\&H 2017, afl. 3, p. 110-117, E.M. van Gelder \& D.A.G. van Toor, Het nemo-teneturbeginsel en de verhouding met de Wet herziening strafbaarstelling faillissementsfraude, TBS\&H 2016, afl. 3, p 161-168 en R.J. van Galen, De wet versterking positie curator. Wordt hierdoor faillissementsfraude beter aangepakt?, OSP 2014/109.

47. Vgl. concl. A-G De Bock bij HR 28 oktober 2016, ECLI:NL:PHR: 2016:1070, par. 3.5
Hoewel de informatiepositie van de curator is versterkt doordat de partner ten aanzien van de gemeenschap ook inlichtingen moet verstrekken over het handelen van de failliet ten aanzien van de gemeenschap, brengt deze versterking complicaties met zich wegens het verschoningsrecht. Een beroep op het verschoningsrecht kost de curator en ook de rechter-commissaris extra tijd, omdat een verhoor ten overstaan van de rechtercommissaris nodig lijkt om het verschoningsrecht te waarborgen. Het was efficiënter geweest als de wetgever rekening had gehouden met het verschoningsrecht, bijvoorbeeld door in artikel 105 lid $3 \mathrm{Fw}$ op te nemen dat de inlichtingen die de partner verstrekt heeft met een beroep op het verschoningsrecht, uitsluitend ten behoeve van het faillissement gebruikt mogen worden. ${ }^{48}$ De positie van de curator zou daarmee bovendien verder zijn versterkt.

Daarnaast rust naar huidig recht op grond van artikel 106 lid 3 Fw wettelijk een medewerkingsverplichting op de partner, voor zover het faillissement de gemeenschap betreft. Op dit punt is de positie van de curator versterkt.

Omdat artikel $87 \mathrm{t} / \mathrm{m} 92 \mathrm{Fw}$, waarin onder meer de inbewaringstelling wordt geregeld, in de Wet versterking positie curator niet van toepassing zijn verklaard op de partner, heeft de curator nog steeds niet de mogelijkheid om de nakoming van de inlichtingen- en medewerkingsplicht van de partner af te dwingen op grond van de Faillissementswet. De curator kan wel in een civiele procedure veroordeling vorderen van de partner om te voldoen aan de inlichtingen- en medewerkingsplicht op straffe van een dwangsom (art. 611a Rv) of lijfsdwang (art, $585 \mathrm{Rv}$ ), maar een dergelijke procedure is tijdrovend. Ook is het opleggen van een dwangsom weinig zinvol indien de partner een algehele gemeenschap van goederen is aangegaan met de failliet. Daarnaast wordt een vordering tot lijfsdwang zelden toegewezen. De wetgever had de positie van de curator verder kunnen versterken door artikel $87 \mathrm{t} / \mathrm{m} 92$ Fw mede op de partner van toepassing te verklaren. ${ }^{49} \mathrm{Nu}$ de curator zijn verzoeken jegens de partner van de failliet nog steeds geen kracht bij kan zetten met een inbewaringstelling, blijft de curator ten opzichte van de partner van de failliet een tijger zonder tanden.

\section{Verplichtingen derden}

Op grond van artikel 105b lid $1 \mathrm{Fw}$ dienen derden die in de uitoefening van hun beroep of bedrijf enige administratie van de failliet onder zich hebben, deze administratie aan de curator ter beschikking te stellen, 'zo nodig met inbegrip van de middelen om de inhoud binnen redelijke tijd leesbaar te maken'. Op grond van lid 2 kunnen deze derden geen beroep doen op een retentierecht als de curator de administratie heeft opgevraagd. Tot slot regelt het derde lid de nietigheid van

48. Vgl. Van Nielen \& Derijks 2014, p. 30. Zie ook C.M. Hilverda, De omvang van de faillissementsrechtelijke inlichtingenplicht, TvI 1997, afl. 1, p. 11-14.

49. Zie reeds de noot van W.H. Heemskerk onder HR 25 juni 1976, NJ $1977 / 495$. 


\section{Maandblad}

Ondernemingsrecht

bedingen die in strijd zijn met de eerste twee leden. Het is de vraag of artikel 105b Fw de positie van de curator daadwerkelijk versterkt.

\subsection{Verplichtingen derden voor de wetswijziging}

Voordat de Wet versterking positie curator in werking trad, is in de rechtspraak meerdere keren geoordeeld dat een derde administratie van de failliet moest overleggen aan de curator. In 2008 oordeelde de voorzieningenrechter bij de Rechtbank Breda dat de curator de privélaptop van een werknemer van de failliet onder zich mocht nemen om administratie van de failliet in te zien en te kopiëren. ${ }^{50}$ Het Gerechtshof 's-Hertogenbosch liet deze uitspraak in stand met een beroep op artikel 92 Fw, waaruit volgt dat de curator administratie van de failliet veilig moet stellen. ${ }^{51}$ In 2013 oordeelde de voorzieningenrechter bij de Rechtbank Oost-Brabant dat de curator onder omstandigheden de bevoegdheid heeft gegevensdragers van derden onder zich te nemen, als aannemelijk is dat daarop administratie van de failliet aanwezig is. De curator mag onderzoek doen om vast te stellen of deze gegevensdragers al dan niet administratie van de failliet bevatten en indien dat het geval is een kopie maken van deze administratie. ${ }^{52}$ De derden in kwestie waren de levenspartner en kinderen van de failliet.

In beginsel moet ook een advocaat van de failliet dossiers overleggen aan de curator. De advocaat komt daarbij geen beroep toe op een retentierecht. ${ }^{53}$ De Hoge Raad oordeelde in 1994 dat advocatendossiers geen verkoopwaarde hebben en zich ook niet lenen voor verkoop. $\mathrm{Nu}$ de curator in het geval dat aan de orde was belang had bij de dossiers, was een beroep op het retentierecht naar maatstaven van redelijkheid en billijkheid onaanvaardbaar. ${ }^{54}$ Sindsdien is het vaste rechtspraak dat geen beroep op het retentierecht gedaan kan worden bij een verzoek van de curator tot overlegging van administratie van de failliet. ${ }^{55}$

Wel kunnen de geheimhoudingsplicht en het verschoningsrecht van de advocaat bij het opvragen van diens dossiers een complicatie vormen. De voorzieningenrechter bij de Rechtbank Utrecht oordeelde in 2006 dat de advocaat zich niet op zijn geheimhoudingsplicht kon beroepen, omdat de curator in de positie van de failliet was getreden. ${ }^{56} \mathrm{Naar}$ het oordeel van de Rechtbank Amsterdam kwam de advocaat echter wel een

50. Rb. Breda (vzr.) 31 juli 2008, JOR 2008/254.

51. Hof's-Hertogenbosch 2 november 2010, JOR 2012/54.

52. Rb. Oost-Brabant (vzr.) 12 juni 2014, JOR 2015/152.

53. Zie over het retentierecht onder oud recht ook Vermaire \& Luijkx 2016

54. HR 15 april 1994, NJ 1995/640 (Middendorf/Kouwenberg q.q.), r.o. 3.4 en 3.5. De grondslag hiervoor is art. $6: 2$ lid $2 \mathrm{BW}$.

55. Advocatendossiers scharen wij ook onder het begrip administratie. Zie ten aanzien van advocatendossiers Rb. Rotterdam 22 november 1994, NJ 1995/641, Hof Amsterdam 28 december 1995, NJ 1998/450 en Rb. Utrecht 16 november 2006, JOR 2016/280. Zie ten aanzien van een administratiekantoor Rb. Arnhem (vzr.) 31 december 1996, JOR $1997 / 23$.

56. Rb. Utrecht (vzr.) 16 november 2006, JOR 2006/280, r.o. 4.5. beroep op het verschoningsrecht toe. ${ }^{57}$ De Hoge Raad heeft zich nog niet uitgelaten over de toepassing van het verschoningsrecht op het overleggen van dossiers aan een curator door verschoningsgerechtigden. Wel heeft de Hoge Raad in het kader van een verhoor door de rechter-commissaris op grond van artikel $223 \mathrm{~b} F w$ (de equivalent in surseance van betaling van art. $66 \mathrm{Fw}$ ) geoordeeld dat een notaris die opgeroepen wordt voor verhoor, een beroep kan doen op het verschoningsrecht. Het verschoningsrecht berust op een algemeen rechtsbeginsel, dat het belang van waarheidsvinding moet wijken voor het belang dat ieder zich vrij en zonder vrees voor openbaarmaking moet kunnen wenden tot een vertrouwenspersoon als een notaris. Dat het verschoningsrecht van een notaris niet expliciet is neergelegd in artikel 223b Fw, doet hieraan niet af. ${ }^{58}$ Deze uitspraak is niet alleen van belang voor de notaris, maar ook voor andere verschoningsgerechtigden, zoals een advocaat. Naar onze mening is de uitspraak van de Rechtbank Amsterdam hiermee in lijn en kon in ieder geval onder oud recht een beroep worden gedaan op het verschoningsrecht en de geheimhoudingsplicht als de curator dossiers en andere administratie opvroeg van een notaris of advocaat. Dat zou echter anders kunnen liggen wanneer de verschoningsgerechtigde administratie van de failliet onder zich heeft die hem niet in het kader van zijn beroep of bedrijf ter beschikking is gesteld. ${ }^{59}$

Wanneer het gaat om het door de advocaat verschaffen van gegevens of verantwoording aan de curator over (de besteding van) gelden van de failliet die de advocaat in beheer heeft of heeft gehad, lag dat anders. In verklaringsprocedures bij beslag ex artikel 476a $\mathrm{Rv}$ is geoordeeld dat het verschoningsrecht en de geheimhoudingsplicht moeten wijken voor de verklaringsplicht. ${ }^{60}$ Daarbij achtte de rechter van belang dat de verhaalsmogelijkheden van schuldeisers ernstig zouden worden gefrustreerd, wanneer advocaten door hun verschoningsrecht niet zouden hoeven verklaren over vorderingen en zaken die door een gelegd beslag zijn getroffen. Het ging in deze zaken om schuldeisers die beslag hadden gelegd ten laste van de schuldenaar. Het faillissement is een algeheel beslag op het vermogen van de failliet. Als een advocaat zich tegenover individuele schuldeisers niet kan beroepen op zijn verschoningsrecht en zijn geheimhoudingsplicht, dan zou de advocaat dat tegenover een curator, die de gezamenlijke schuldeisers vertegenwoordigt, evenmin moeten kunnen. Op dit punt biedt de wet echter geen duidelijkheid, wat naar onze mening een gemiste kans is in het kader van de versterking van de positie van de curator.

Over het verstrekken van middelen aan de curator om de administratie (binnen redelijke termijn) leesbaar te maken, was de jurisprudentie verdeeld. ${ }^{61}$ Dat de curator belang heeft

57. Rb. Amsterdam 27 juli 2011, JOR 2012/24.

58. HR 1 maart 1985, NJ 1986/173 (Maas II).

59. Zie Rb. Rotterdam 23 maart 2017, ECLI:NL:RBROT:2017:3326.

60. Zie Rb. Amsterdam 4 augustus 2004, NJF 2004/540 en Rb. Amsterdam 3 juli 2014, JOR 2014/283.

61. Zie over administratie in de cloud onder oud recht Bosvelt \& Van Oijen 2013. 
bij het verkrijgen van software en diensten van derden om ruwe data inzichtelijk te maken, volgt beeldend uit een uitspraak van het Gerechtshof's-Hertogenbosch uit 2013:

'Ter vergelijking kan worden gedacht aan alle telefoonboeken van Nederland die door een shredder zijn gegaan; alles staat erop, maar de verbanden zijn weg, aldus Vict in een email aan de curator van 24 oktober 2011 (...). De onbegrijpelijke en onleesbare stroom aan informatie wordt eerst inzichtelijk en bruikbaar indien de door Vict geleverde software en diensten kunnen worden benut.' ${ }^{32}$

In deze uitspraak overwoog het hof, in lijn met de voorzieningenrechter, ${ }^{63}$ dat de serviceprovider (Vict) niet gehouden was om de dienstverlening voort te zetten. De curator had de overeenkomst met de serviceprovider namelijk niet gestand gedaan en geen zekerheid gesteld voor de nakoming in de zin van artikel 37 Fw. Naar het oordeel van het hof mocht de serviceprovider een commerciële vergoeding vragen voor het voortzetten van de dienstverlening. ${ }^{64}$ De curator had geen recht op 'kosteloze dienstverlening'. Dit is met name problematisch als de boedel onvoldoende middelen heeft om de serviceprovider te betalen. ${ }^{65}$ De curator moet dan afzien van de verlangde dienstverlening, of de kosten zélf (vanuit zijn kantoor) voorschieten met het risico van een lege boedel. De voorzieningenrechter bij de Rechtbank Oost-Brabant oordeelde meer in het voordeel van de curator. Volgens de voorzieningenrechter vloeit uit artikel 92 Fw voort dat de partij die clouddiensten levert, deze diensten tegen een redelijke vergoeding moet voortzetten jegens de curator. ${ }^{66}$ Artikel $37 \mathrm{Fw}$ speelde overigens in de laatste casus geen rol, omdat de hostingpartij geen overeenkomst had met de failliet maar met een andere rechtspersoon. ${ }^{67} \mathrm{~W}$ at een redelijke vergoeding is, volgt niet uit de uitspraak van de voorzieningenrechter. ${ }^{68}$

\subsection{Wet versterking positie curator}

Door de invoering van de Wet versterking positie curator dienen derden die in de uitoefening van hun beroep of bedrijf administratie van de failliet onder zich hebben, deze op grond van artikel 105b lid $1 \mathrm{Fw}$ aan de curator ter beschikking te stellen. Het begrip administratie is niet gedefinieerd in artikel $105 \mathrm{~b}$ Fw. Uit de wetsgeschiedenis volgt dat het een breed begrip is. Volgens de minister kan ter illustratie worden gewezen op 'de boekhouding, de financiële en fiscale administratie,

62. Hof's-Hertogenbosch 26 maart 2013, JOR 2013/192, r.o. 3.2.

63. Rb. 's-Hertogenbosch (vzr.) 20 maart 2012, ECLI:NL:RBSHE: 2012:BV9640.

64. Hof's-Hertogenbosch 26 maart 2013, JOR 2013/192, r.o. 3.7.

65. Zie ook de noot van W.J.B. van Nielen in JOR 2013/192. Naar zijn mening was het onder oud recht denkbaar dat de serviceprovider ondanks de lege boedel de dienstverlening zou moeten continueren.

66. Rb. Oost-Brabant (vzr.) 13 februari 2015, JOR 2015/216.

67. W.J.B. van Nielen in zijn noot onder Rb. Oost-Brabant (vzr.) 13 februari 2015, JOR 2015/216.

68. Zie ook B. Wessels, De curator en de cloud, NJB 2015/639, waarin op basis van een uitspraak van de Rb. 's-Hertogenbosch (14 november 2012, JOR 2013/68) een indicatie wordt gegeven van een redelijke vergoeding. een eventuele goederenadministratie, zakelijke correspondentie, accountantsverklaringen en jaarstukken, betaalde en gefactureerde nota's alsmede in- en uitgaande emailcorrespondentie (...)'.69 Naar onze mening vallen bijvoorbeeld ook advocatendossiers onder omstandigheden onder het begrip administratie. Daarbij valt te denken aan een dossier ten aanzien van een vordering die door de failliet is ingesteld jegens een derde. De curator heeft dit dossier in de regel nodig om in te schatten of de ingestelde vordering kans van slagen heeft, en of hij de procedure wil overnemen in de zin van artikel $27 \mathrm{Fw}$.

Dat in artikel $105 \mathrm{~b}$ lid $1 \mathrm{Fw}$ is vastgelegd dat derden administratie van de failliet aan de curator moeten overleggen, zorgt niet voor een versterking van de informatiepositie van de curator, nu deze verplichting al werd aangenomen. De redactie van artikel $105 \mathrm{~b}$ lid $1 \mathrm{Fw}$ beperkt zich echter tot derden die de administratie van de failliet onder zich hebben in de uitoefening van hun beroep of bedrijf. Werknemers, de partner van de failliet, de kinderen van de failliet en overige derden die geen beroep of bedrijf uitoefenen, vallen niet onder de reikwijdte van artikel $105 \mathrm{~b}$ lid $1 \mathrm{Fw}$. De wetsgeschiedenis lijkt zelfs uit te gaan van een nog beperktere reikwijdte. Op een vraag van de CDA-fractie of artikel 105b Fw ook van toepassing is op financiële instellingen, antwoordt de minister dat vooral gedacht is aan externe administratiekantoren en 'niet in algemene zin aan financiële instellingen'. ${ }^{70}$ Onder oud recht werd de verplichting om administratie van de failliet te overleggen voor een ruimere groep derden afgeleid uit artikel $92 \mathrm{Fw}$. Het is de vraag hoe deze ruime interpretatie van artikel $92 \mathrm{Fw}$ zich thans verhoudt tot artikel 105b lid 1 Fw. Het lijkt er door de beperkte formulering van artikel $105 \mathrm{~b}$ lid $1 \mathrm{Fw}$ op dat de groep derden die administratie van de failliet moet overleggen aan de curator na inwerkingtreding van de Wet versterking positie curator beperkter is geworden. Wij vragen ons af of dit de bedoeling van de wetgever is geweest. Artikel 105b lid $1 \mathrm{Fw}$ zou ook als een verduidelijking kunnen worden gezien van de spelregels die gelden in de situatie dat een curator administratie bij een derde in de uitoefening van zijn of haar beroep of bedrijf opeist, zonder dat die verduidelijking afbreuk doet aan de verplichtingen voor andere derden die volgden uit reeds gewezen jurisprudentie onder artikel 92 Fw. In dat geval is de positie van de curator niet gewijzigd.

Uit artikel 105b lid 2 Fw volgt dat derden die administratie van de failliet onder zich houden, geen beroep op het retentierecht kunnen doen. Een hiermee strijdig beding is nietig op grond van lid 3 van dat artikel. Dat derden geen beroep op het retentierecht kunnen doen, is geen versterking van de positie van de curator. Onder oud recht was het immers vaste rechtspraak dat een beroep op het retentierecht naar maatstaven van redelijkheid en billijkheid onaanvaardbaar was. De grond-

69. Kamerstukken II 2015/16, 34253, 6, p. 16. Dat e-mailcorrespondentie onder de administratie valt, blijkt ook uit Hof Den Haag 11 maart 2014, JOR 2014/218.

70. Kamerstukken II 2015/16, 34253, 6, p. 23 en 24 . 


\section{Maandblad}

Ondernemingsrecht

slag waarmee een beroep op het retentierecht wordt verhinderd, is veranderd, maar materieel is het resultaat gelijk.

Onder de Wet versterking positie curator blijft discussie met advocaten en notarissen over het verschoningsrecht en de geheimhoudingsplicht mogelijk. In de wet wordt de verhouding tussen artikel 105b Fw en het verschoningsrecht niet geregeld. In de wetsgeschiedenis wordt hierop ook niet ingegaan. $\mathrm{Nu}$ de Hoge Raad heeft geoordeeld dat het verschoningsrecht berust op een algemeen rechtsbeginsel en het verschoningsrecht ook geldt als dit niet expliciet in de wet is opgenomen, ${ }^{71}$ blijft het voor advocaten en notarissen nog steeds mogelijk om ten aanzien van bepaalde stukken een beroep op het verschoningsrecht te doen. Dat de verhouding tussen artikel 105b Fw en het verschoningsrecht niet is geregeld, blijft dus een mogelijk knelpunt voor de curator.

Voor het geval door derden software moet worden verstrekt of diensten moeten worden verleend om de administratie leesbaar te maken, is de positie van de curator aanzienlijk versterkt. Uit artikel $105 \mathrm{~b}$ lid $1 \mathrm{Fw}$ volgt dat derden de administratie ter beschikking moeten stellen aan de curator, 'zo nodig met inbegrip van de middelen om de inhoud binnen redelijke tijd leesbaar te maken'. Ook de leverancier van clouddiensten zal administratie die hij onder zich heeft, beschikbaar moeten stellen aan of beschikbaar moeten houden voor de curator. ${ }^{72}$ Uit de wetsgeschiedenis volgt dat derden een redelijke vergoeding kunnen vragen aan de curator, maar dat derden hun verplichtingen uit artikel 105b Fw ook moeten nakomen als de curator geen mogelijkheid heeft een redelijke vergoeding te betalen uit de boedel. Derden kunnen het risico van lege boedels volgens de minister in hun tarieven verdisconteren. ${ }^{73}$ Daar waar het risico dat de vergoeding niet uit de boedel betaald kon worden onder oud recht bij de curator lag, ligt dit risico nu bij de derde. Overigens blijft discussie mogelijk tussen de curator en de derde over de hoogte van de vergoeding. Uit de wet en Kamerstukken blijkt namelijk niet wat een redelijke vergoeding is en hoe deze berekend moet worden. Naar onze mening is een redelijke vergoeding (ongeveer) de kostprijs.

Wij nemen overigens aan dat de redelijke vergoeding die de dienstverlener kan vorderen, een concurrente boedelvordering is. ${ }^{74}$ De Hoge Raad heeft geoordeeld dat boedelschulden naar evenredigheid moeten worden voldaan, behoudens de daarvoor geldende wettelijke redenen van voorrang. ${ }^{75}$ Deze derde heeft geen voorrang, omdat de wet in artikel 105b Fw geen voorrang verleent aan de derde en voorrang ook niet geldt op

71. HR 1 maart 1985, NJ 1986/173 (Maas II).

72. Kamerstukken II $2015 / 16,34253,3$, p. 21.

73. Kamerstukken II 2015/16, 34253, 6, p. 16, 18, 21 en 24. Zie ook Kamerstukken II 2015/16, 34253, 3, p. 11.

74. Ook Vermaire en Luijkx nemen aan dat deze derde een boedelvordering krijgt, maar zij laten zich niet uit over de rang van die vordering (Vermaire \& Luijkx 2016).

75. HR 28 september 1990, NJ 1991/305 (De Ranitz q.q./Ontvanger). Vgl. art. 3:277 lid $1 \mathrm{BW}$ basis van enig ander wetsartikel. Wanneer de boedel onvoldoende middelen bevat om de concurrente boedelcrediteuren te voldoen, zal de factuur van de dienstverlener onbetaald blijven, terwijl die derde wel aan de afgifteplicht jegens de curator heeft moeten voldoen. Dit lijkt ons een versterking van de positie van de curator.

\section{Conclusie}

\subsection{Verduidelijkingen positie curator}

De wetgever heeft met de Wet versterking positie curator beoogd de informatiepositie van de curator te versterken en te verduidelijken. ${ }^{76}$ Veel onderdelen van de wet zijn een codificatie van jurisprudentie. Op deze onderdelen is de informatiepositie van de curator feitelijk niet versterkt, maar wel verduidelijkt. Door de codificatie is voor betrokkenen duidelijk wat van hen verwacht wordt. Dit geeft de curator meer houvast als hij de failliet en anderen wil houden aan de verplichtingen die zij hebben.

Zo is de positie van de curator onder meer verduidelijkt ten aanzien van derden die in de uitoefening van hun bedrijf of beroep administratie van de failliet onder zich houden. Paradoxaal gezien roept deze verduidelijking wel de vraag op of de verplichting de administratie over te dragen ook voor andere derden geldt, zoals voor inwerkingtreding van de wet het geval was. Onder oud recht werd een verplichting van alle derden om administratie van de failliet over te leggen afgeleid uit artikel 92 Fw. Nu artikel 105b lid 1 Fw ten aanzien van specifieke derden expliciet bepaalt dat zij administratie van de failliet moeten verstrekken aan de curator, is onduidelijk of de rechtspraak artikel $92 \mathrm{Fw}$ nog zo uit zal leggen dat ook andere derden deze verplichting hebben. Wij menen van wel, omdat de wetgever immers een versterking van de positie van de curator heeft beoogd.

\subsection{Knelpunten positie curator}

Duidelijk is dat de inlichtingenplicht in alle situaties geldt voor gewezen bestuurders. Hiermee is de positie van de curator naar onze mening niet versterkt, maar wel verduidelijkt. De inlichtingen- en medewerkingsplicht geldt echter uitsluitend voor degenen die in de drie jaar voorafgaand aan de faillietverklaring bestuurder waren, terwijl het heel goed mogelijk is dat ook personen die langer dan drie jaar voor de faillietverklaring hun hoedanigheid van bestuurder hebben verloren relevante informatie bezitten voor de curator. De gewiekste fraudeur dient thans te zorgen dat hij een stroman aanstelt die de vennootschap nog drie jaar laat 'bungelen' alvorens de vennootschap failleert, zodat hij zelf buiten schot blijft. In de praktijk kan dit een knelpunt zijn voor de curator.

Op sommige punten heeft de wetgever geen duidelijkheid of versterking geboden. Hoewel in de literatuur is verdedigd dat de inlichtingen- en medewerkingsplicht ook zou moeten gel-

76. Kamerstukken II 2014/15, 34253, 3, p. 5 en 6 . 
den voor de lokale manager in Nederland van een buitenlandse rechtspersoon, heeft de wetgever dit niet opgepakt. Een gemiste kans is ook dat niet is vastgelegd dat de inlichtingenplicht niet beperkt is tot feiten en omstandigheden waarvan de persoon uit hoofde van zijn functie kennis droeg, en ook niet beperkt is tot zijn eigen administratie, maar mede ziet op inlichtingen die betrekking hebben op het vermogen van gelieerde (rechts)personen die niet failliet zijn. Daarnaast blijft de positie van de curator tegenover de partner van de failliet zwak, omdat de curator nog steeds niet de mogelijkheid heeft om de nakoming van verplichtingen van de partner af te dwingen door middel van een verzoek tot inbewaringstelling op grond van artikel $87 \mathrm{Fw}$. De wetgever biedt voorts geen duidelijkheid voor de gevallen dat de curator informatie bij geheimhouders (advocaten/notarissen) opvraagt over geldstromen van de failliet die lopen via de (derden)rekening van die geheimhouder. Tot slot blijven de geheimhoudingsplicht en het verschoningsrecht een punt van discussie als de curator advocatendossiers opvraagt. De wet en toelichting besteden geen aandacht aan dit probleem.

\subsection{Versterking positie curator}

We eindigen met een positieve noot. Op bepaalde punten is de informatiepositie van de curator daadwerkelijk versterkt. De positie van de curator is versterkt tegenover de partner van de failliet. De inlichtingenplicht van de partner is niet meer beperkt tot het eigen handelen. De partner moet thans ook informatie verstrekken aan de curator over het handelen van de failliet. Deze versterking brengt wel complicaties met zich in het kader van het verschoningsrecht. Ook is in de wet een medewerkingsplicht opgelegd aan de partner, terwijl die plicht naar onze mening onder oud recht niet op de partner rustte. Tot slot is de positie van de curator versterkt ten opzichte van derden die naast administratie van de failliet ook software of diensten moeten leveren om de administratie van de failliet leesbaar te maken. Deze derden kunnen hiervoor een redelijke vergoeding vragen aan de curator, maar moeten hun verplichting ook nakomen wanneer die vergoeding niet kan worden voldaan uit de boedel. Onder oud recht lag het risico van een lege boedel in dit soort situaties bij de curator, omdat hij geen recht had op 'kosteloze dienstverlening'.

Wij concluderen dat de titel van deze wet de lading niet helemaal dekt. De informatiepositie van de curator is gewijzigd, maar van een versterking over de gehele linie kan niet worden gesproken. De praktijk zal moeten uitwijzen of curatoren met deze nieuwe wet in de hand faillissementsfraude beter kunnen bestrijden, zoals de wetgever voor ogen heeft gehad.

Wettekst voor 1 juli 2017

\section{Bijlage: wetteksten}

\section{Artikel 105}

1. De gefailleerde is verplicht voor de rechter-commissaris, de curator of de commissie uit de schuldeisers te verschijnen en deze alle inlichtingen te verschaffen, zo dikwijls hij daartoe wordt opgeroepen.

2. Bij een faillissement van een persoon die in gemeenschap van goederen is gehuwd of in gemeenschap van goederen een geregistreerd partnerschap is aangegaan, rust de verplichting om inlichtingen te geven op ieder van de echtgenoten onderscheidenlijk van de geregistreerde partners voorzover hij gehandeld heeft.

\section{Artikel 106}

Bij het faillissement van een rechtspersoon zijn de bepalingen van de artikelen 87-91 op de bestuurders, die van artikel 105, eerste lid, op bestuurders en commissarissen toepasselijk.

\section{Wettekst vanaf 1 juli 2017}

\section{Artikel 105}

1. De gefailleerde is verplicht de curator, de schuldeiserscommissie en de rechter-commissaris alle inlichtingen te verschaffen als dit van hem wordt verlangd, op de wijze als daarbij is bepaald. De gefailleerde licht de curator eigener beweging in over feiten en omstandigheden waarvan hij weet of behoort te weten dat deze voor de omvang, het beheer of de vereffening van de boedel van belang zijn.

2. De gefailleerde die in het buitenland vermogensbestanddelen heeft, zoals banktegoeden of onroerend goed, is verplicht:

a. de curator daarover in te lichten; en

b. alle medewerking te verlenen, waaronder zo nodig de verschaffing van een volmacht, om de curator de beschikking te geven over die buitenlandse vermogensbestanddelen.

3. Indien de gefailleerde in enige gemeenschap van goederen is gehuwd of in enige gemeenschap van goederen een geregistreerd partnerschap is aangegaan, rust de plicht om inlichtingen te geven op ieder van de echtgenoten onderscheidenlijk van de geregistreerde partners voor zover het faillissement de gemeenschap betreft.

\section{Artikel 105a}

1. De gefailleerde verleent de curator alle medewerking aan het beheer en de vereffening van de boedel.

2. De gefailleerde draagt terstond de administratie en de daartoe behorende boeken, bescheiden en andere gegevensdragers volledig en ongeschonden aan de curator over. Zo nodig stelt de gefailleerde de curator alle middelen ter beschikking om de inhoud binnen redelijke termijn leesbaar te maken.

3. Indien de gefailleerde in enige gemeenschap van goederen is gehuwd of in enige gemeenschap van goederen een geregistreerd partnerschap is aangegaan, rust de plicht om medewerking te verlenen op ieder van de echtgenoten onderscheidenlijk van de geregistreerde 
partners voor zover het faillissement de gemeenschap betreft.

\section{Artikel 105b}

1. Derden met inbegrip van accountantsorganisaties en een externe accountant, die in de uitoefening van hun beroep of bedrijf, op welke wijze dan ook, de administratie van de gefailleerde geheel of gedeeltelijk onder zich hebben, stellen die administratie en de daartoe behorende boeken, bescheiden en andere gegevensdragers desgevraagd volledig en ongeschonden aan de curator ter beschikking, zo nodig met inbegrip van de middelen om de inhoud binnen redelijke tijd leesbaar te maken.

2. In afwijking van artikel 60 kunnen derden geen beroep op een retentierecht doen ten aanzien van de administratie van de gefailleerde die zij in de uitoefening van hun beroep of bedrijf, op welke wijze dan ook, onder zich hebben als de curator die administratie op grond van het eerste lid heeft opgevraagd.

3. Elk beding dat strijdig is met het bepaalde in het eerste of tweede lid is nietig.

\section{Artikel 106}

1. Bij het faillissement van een rechtspersoon zijn de bepalingen van de artikelen 87 tot en met 92, 105, eerste en tweede lid, alsmede 105a, eerste en tweede lid, op bestuurders en commissarissen toepasselijk alsmede op eenieder die in de drie jaar voorafgaande aan het faillissement bestuurder of commissaris was.

2. Met een bestuurder wordt voor de toepassing van het eerste lid gelijkgesteld:

a. degene die het beleid van de rechtspersoon heeft bepaald of mede heeft bepaald als ware hij bestuurder;

b. de bestuurder van een of meer rechtspersonen alsmede de vennoot van een of meer vennootschappen onder firma of commanditaire vennootschappen die bestuurder is of zijn van de failliete rechtspersoon.

3. Bij het faillissement van een vennootschap onder firma of een commanditaire vennootschap zijn de eerste twee leden van overeenkomstige toepassing. 